\title{
LABORATORY TRAINING TO SUPPORT AUTOMOTIVE ENGINEERING SKILLS
}

\author{
Andrea LE $\breve{S} K O V A ̈$
}

\begin{abstract}
The presented article deals with educational practice for automotive engineering at Faculty of Mechanical Engineering, Technical University of Košice, in flexible and adaptable laboratory classroom. This paper focuses on presentation of reference model of training laboratory for automotive engineering based on good practice, correspondents with requirements for visual learning and action learning of Product Design approach. The closing section of the article provides the vision of the information technology support to using the visualization in training process of automotive engineering.
\end{abstract}

Key words: automotive engineering, training laboratory, visualization.

\section{TRÉNINKOVÁ VÝUČBA PRO ZÍSKÁNÍ ZKUŠENOSTÍ V OBORU AUTOMOBILOVÁ VÝROBA}

Resumé: Př́spěvek je zaměřen na popis tréninkové výuky budoucích inženýrů pro odvětví automobilové výroby, která probíhá na Strojní fakultě Technické univerzity v Košicích v specificky zř́zených a adaptabilních laboratorních prostorech. V článku je prezentován modelový př́íklad vybavení a využití tréninkové laboratoře $\mathrm{z}$ praxe, která podporuje názornou vizualizaci $\mathrm{v}$ procesu vzdělávání a získávání zkušeností o konstrukci a navrhování designu automobilů. Závěrem je v souvislosti s akutní potřebou modernizace výuky načrtnutá vize aplikovat pro zkvalitnění tréninkového procesu informační technologie a nástroje pro vizualizaci inženýrských aktivit v automobilové výrobě.

Klíčová slova: automobilová výroba, inženýrství, tréninková laboratoř, vizualizace.

\section{Introduction}

In recent years, a lot of innovations and new technologies in automotive make necessary the modification of training systems. The utilisation of progressive IT tools for computer aided engineering works causes the changes occurring in automotive engineering profession, e.g. in the field of $\mathrm{R} \& \mathrm{D}$, design, manufacturing, testing, maintenance etc.

Effective training of students means learning through experiences - so knowledge about automobile design principles must be create through the transformation of experience in practical laboratory.

\section{Laboratory of Automotive production}

The laboratory standing at FME TU Košice represents the pilot model of multifunction working places with focusing on components, modules and automobile systems, technology of their production and management of supplying systems for automotive industry. [2]

Equipment of laboratory consist of [3]: bodywork of VW Polo; testing cars: Škoda Octavia, Škoda Fabia Sedan, Kia Sportage, Kia
Ceed, Peugeot 207; prototype of student's car iCAR 2010; models of student's car design proposals; workplace for assembly and disassembly of units; workplace to handmade models and samples from easily machinable materials; workplace for measurement of autoelectronic; testing room for lifespan tests of door hinge system of a car; prototype manufacturing workstation; station to digitizing of automotive parts with 3D measuring arm FARO Platinum Arm and laser scanning head and the software PolyWorks Inspector, touch 3D scanner Microscribe; techniques of automotive Product Design - Autodesk Maya, Rhinoceros, Adobe Creative Suite, Goldfire Innovator; section of seat systems, section of dashboard of car; diagnostics stand with software AutoVAC; vacuum technological equipment for the production of components of composite materials; workplace for consulting and brainstorming; PC room. Examples of selected laboratory facilities are illustrated at fig. 1. [3] 


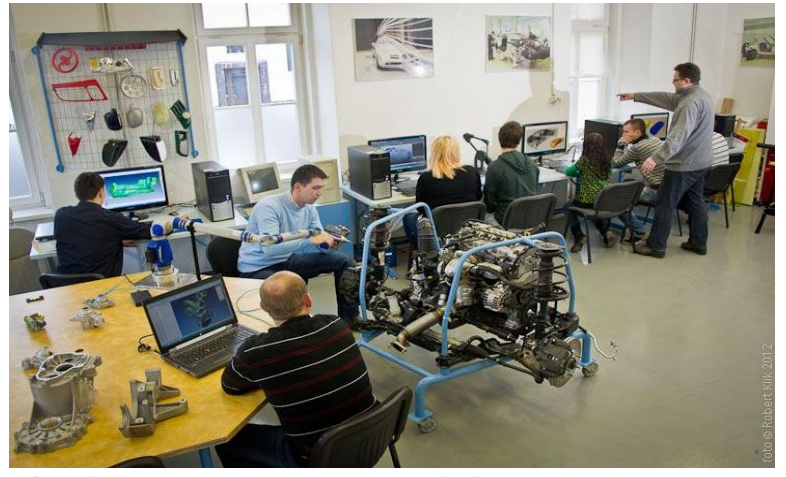

Fig. 1: Automotive training laboratory at FME.

The laboratory integrates the experimental research of innovation projects, cooperation with practice and learning-by-doing education, with primary focus on the following areas: Product Design, methods and techniques for design optimization - design for manufacturing, design for assembly, design for disassembly, design to cost etc. and automotive engineering approach in manufacturing, design and innovation as knowledge intensive services. [1]

\section{Training system for engineers in automotive}

At fig. 2 is visible reference model of training laboratory for automotive engineering that could be considered as optimal adaptable solution, with reconfigurable equipment and accessories. [4] graphics, practical exercises, animations and knowledge tests.

Courses convey the knowledge fundamentals, principles, attributes and skills needed to understand modern automotive systems. Students will be introduced to the complex subjects by a combination of conventional, e-learning courses and practical training with real-life compact automotive systems. Visual training system will consists of a series of A4-format panels with original components from automobile systems. Original automotive components provide an ideal blend of theory and practice. A multimedia program will provide helpful information about the individual components and overall systems. All components are described in detail in technical documentation. Functions are elucidated by videos and animations. Education of the fundamentals of management, mechanical and electrical engineering is a prerequisite for understanding the complex relationships between various automotive applications. Multimedia detailed presentations of functionality of automotive components allow efficient independent learning. [5]

In the course of working on projects and during self-monitored learning processes, young people discover the fascination of automotive technology.

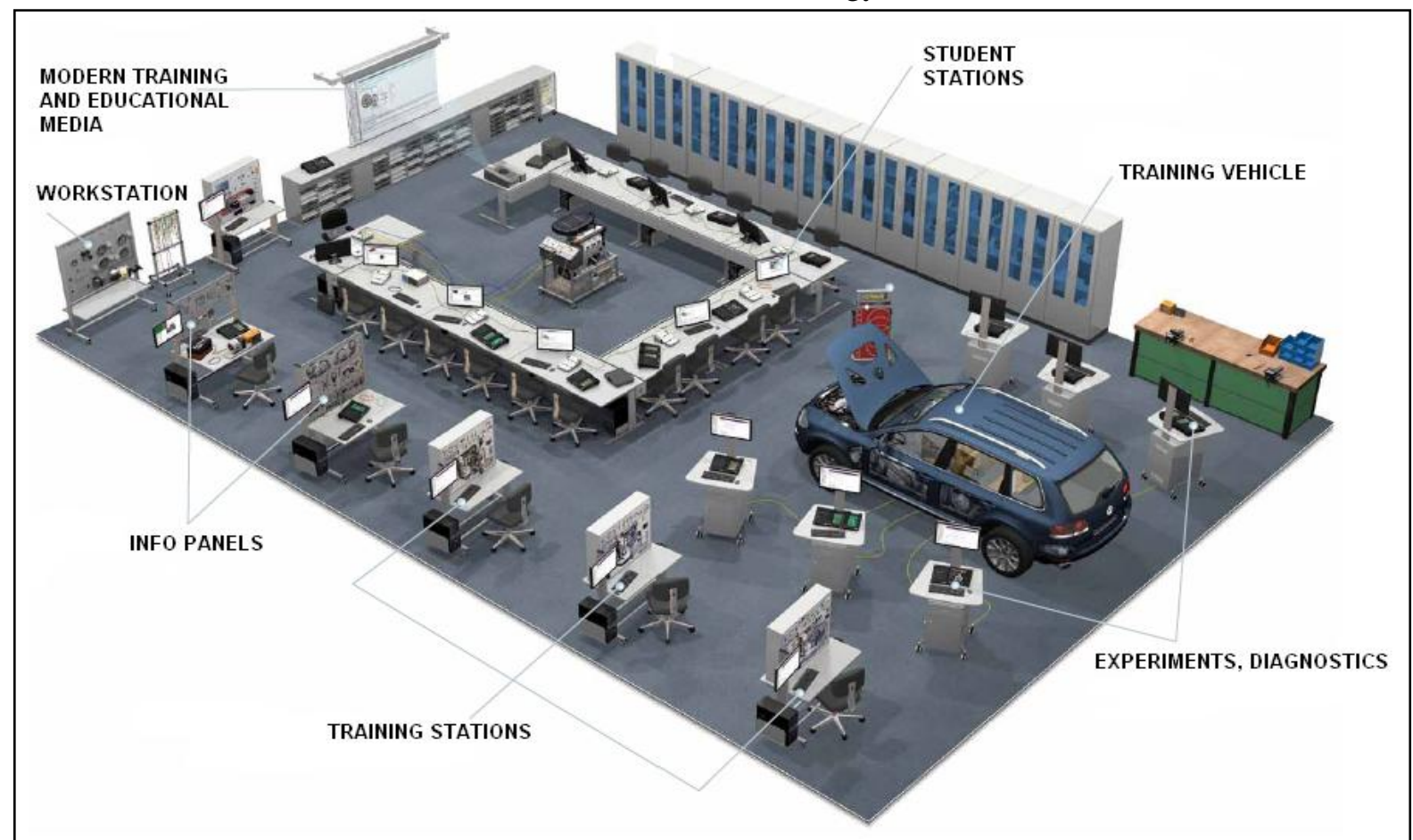

Fig. 2: Example of Laboratory of Project-oriented Learning for Automotive Engineering. [4]

It was necessary to prepared educational and training system, with which students are guided through the experiments, including texts,
Students are learned by manner of seminars and workshops, through study and at the same time through experience, in traditional classroom 
and laboratory style of training. For example, Lab for Automotive Engineering [6] is suitable for demonstrations, practical laboratory work, independent studies and projects, and group work. Presentation slides provide support for lessons, e.g. supplying background information, block diagrams, structural fundamentals, standard characteristics, special modifications and application examples. Stands with modern measurement technology (with PC interface) are characterized by modular design for versatility and flexibility and forms the clear layout of Lab. In the centre of the classroom is placed Training Vehicles - to practical form of education (see fig. 3). To make training as practical as possible, training vehicles are modified specifically for educational purposes. Students can learn typical assembly and dismantling tasks, identifying components. [7]

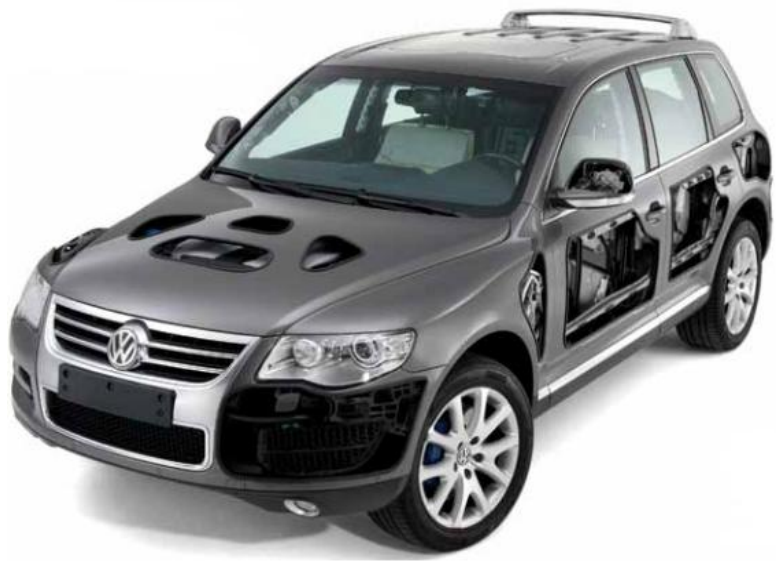

Fig. 3: Example of cut-away car model to supported education. [7]

The didactically-prepared high-quality motor vehicle permits unobstructed visual access to the interior of the car body and thus reveals and provides access to the installation location of many of the control units, thus facilitating the particularly effective demonstration of measurements and control processes. The motor vehicle is also fully functional and can be used in any and all types of instruction. Main benefits for students are [6]: practice-oriented training with original vehicles and components, all components are fully functional, can be interpreting technical documentation, conducting direct measurements on the motor vehicle/engine without assembly or disassembly and conducting measurements on all systems with the engine running, examination of electrical and mechanical components. Trainees also learn to carry out diagnostics and maintenance. [8] The high-quality equipment and instrumentation inside the vehicle allows for a large range of training content to be covered. Besides the externally accessible cut-away car body, there are also many completely open components and parts in the interior of the vehicle, e.g. the interior of the passenger seat, allowing for visual access under the interior lining. [7]

Automotive training consists generally of three main phases [6]:

- structural analysis and specification of training object (a part or an assembly node of the experimental automobile);

- theoretical preparation of students knowledge collection; and finally

- the practical realization, where the training object is disassembled and re-assembled, or tested.

Training system for automotive engineering is based on [5]:

- visual learning methods - they enable to present a dynamic visualization instructional videos, clips and animations (instead of presenting only the static pictures) and

- learning by doing practical methods, with

- Information Technology tools - allows interpreting education and ICT supported education (e.g. simulations).

The main advantages, compared to conventional process of learning, are: project orientation, better motivation of beneficiaries who can verify the theoretical knowledge in practice and compare their results with others and also the improvement of their innovation thinking. [9]

Practical exercises and well-grounded theoretical background information form the foundation for one of the key competences: excellent hands-on skills. The trainee already develops these skills during the training period. This is because individual learning and positive feedback are part of the didactic concept. [10]

Using modular and scalable learning and training systems the foundation is laid for an enduring, continuously up-dated training and educational program at the workplace. Students are introduced to the complex subjects by a combination of e-learning courses and real-life compact systems, and are able to apply acquired skills on true replicas of original components. [9] 


\section{ICT support of training in automotive}

The training system is designed to create optimal learning conditions for practice-oriented instruction. With the multimedia experiment and training system for automotive engineering skills, students are guided through the courses. [8]

Trainers often turn to technology to make learning active, collaborative and visual. Technology has enormous potential to make training sessions more compelling. Digital content is a powerful tool for modern training to transform the learning experience. Educational video network tools are very important to effective training process. [10] This network is operated via a teacher's keyboard. Example of installation possibilities is presented at fig. 4.:

a) Teacher can transmit screens to individual students or groups.

b) The teacher can transmit screens to all students at once.

c) Teachers can also receive images from any student's screen.

d) The screen on any of the students' monitors can be sent to other students.

e) Teachers can switch off the screen for individual students or all at once.

f) An integrated projector means that the teacher's or students' screens can also be projected in large format.

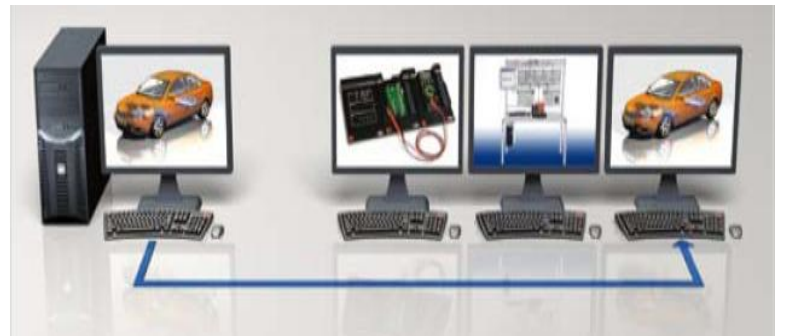

a)

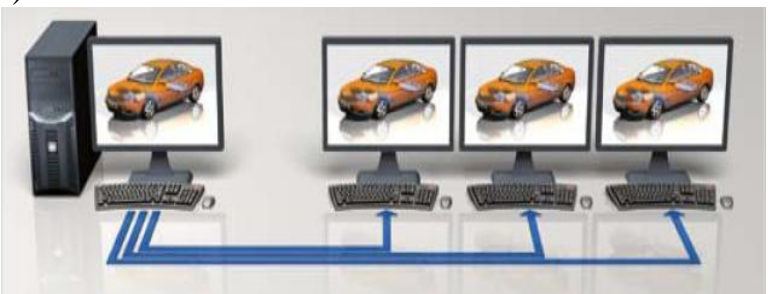

b)

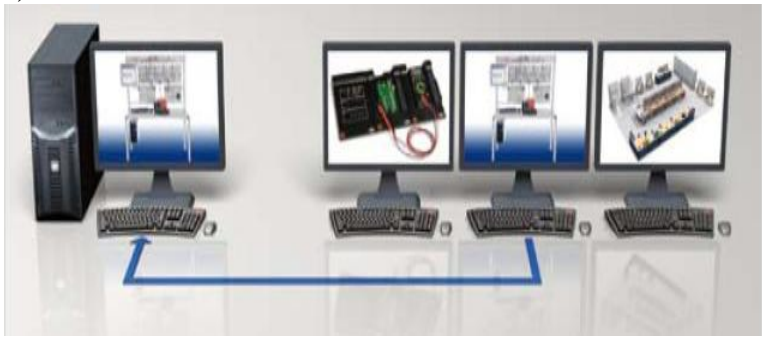

c)

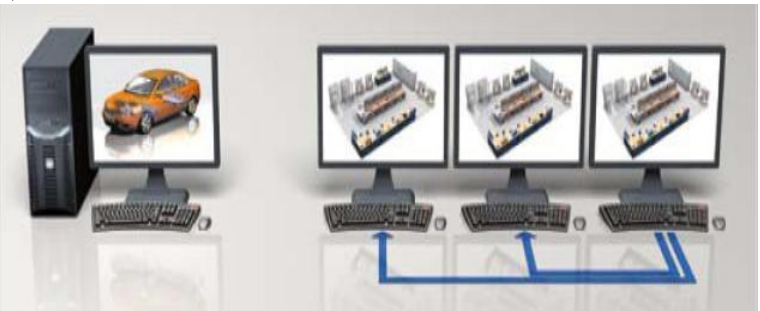

d)

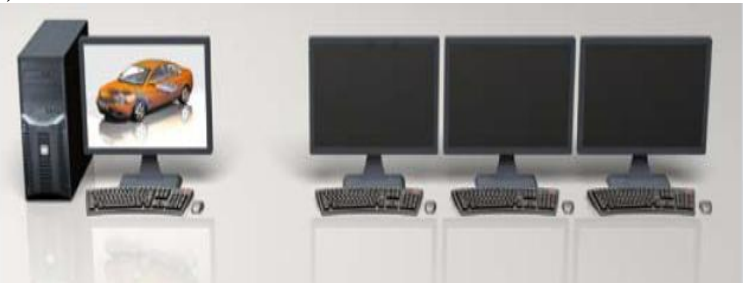

e)

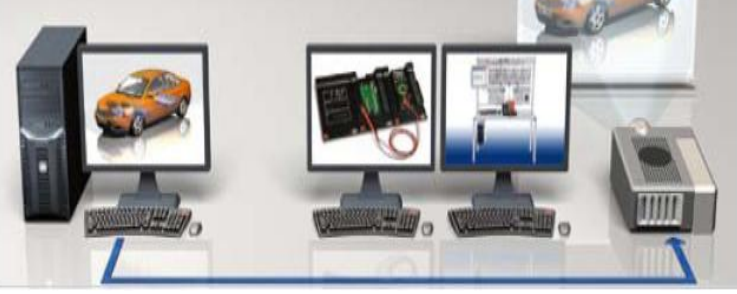

f)

Fig. 4: Examples of display monitor screens to other students in real time. [10]

A simple press of a button transmits what is being shown on the teacher's screen in real time without delay. The keyboard layout can be individually configured according to the seating arrangements in the classroom. The only requirement for connecting up the video network is that there are functioning personal computers with DVI video and USB ports for mouse and keyboard at each workstation. [8] There is a free choice of operating system.

The ICT posed enormous opportunities for improving training and education. By networking workstations, it is possible to make content such as training programs, experiment instructions and tests available from a central server.

Can be summarized benefits of educational video network solutions in laboratory specifications [11]:

- Encourages students to pay more attention.

- Gives students more motivation by providing for individual presentation possibilities.

- Optimum view even for the back row. 
- Does not overload networks, no incompatibility problems.

- Screens transmitted in real time (no delay) even in large rooms.

- Simple operation even for unfamiliar users.

In case of automotive engineering training, based on teamwork, ICT tools of visualization allow to students brainstorm, work on schematics and designs, analyze data, review schedules etc. Many solution and products make training sessions visual and interactive, so teacher can communicate information and e.g. new car concepts more clearly and in greater detail, and trainees can learn at a quicker pace and retain information more effectively. [12] Some examples show fig. 5 .
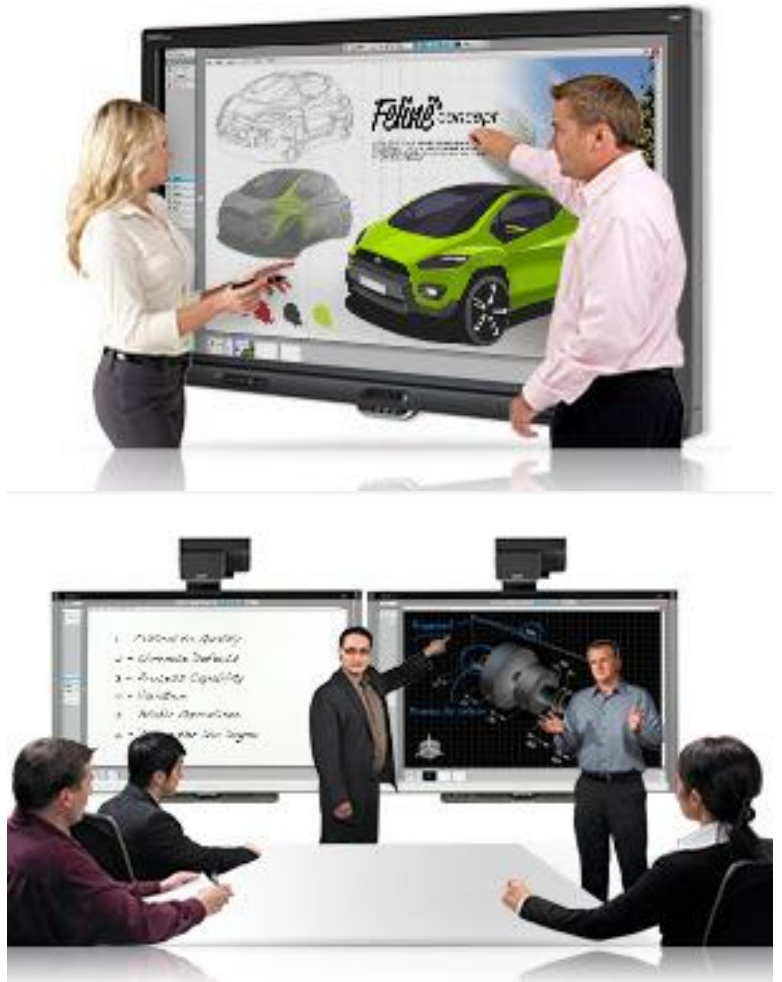

Fig. 5: Examples of ICT support training in automotive Product Design. [12]

Interactive learning sessions are now an integral part of training - training programs become collaborative, so participants can explore new concepts in many different ways and acquire skills quickly. For example, 3D telepresence makes learning easier and provides expert from practice to participate in teaching at a distance. The evolution of education has brought increasing expectation from the students who expect their learning experience to provide exposure to international and local experts and industry. [12] These solutions help accelerate learning. By connecting participants with conferencing software, they can share information digitally, in real time. Remote participants see what teacher see and what teacher write in digital ink over applications. The software enables to have two-way conversations with remote participants. Because teacher can also see their desktops, it's easy to explain a concept, field complex questions or check for comprehension. [12]

Implementation of ICT solutions can help transform training programs [10]:

- Add interactivity: Participants can work directly on the display to analyze problems, perform exercises or write notes in digital ink.

- Use multimedia resources: Explaining concepts on a large screen with videos, images or charts gives you many ways to break down concepts and demonstrate processes.

- Increase efficiency and make learning collaborative: interactive whiteboard or display is a highly visible focal point for participants, enabling the trainer to lead discussions around a common frame of reference. Some of ICT products allow two people to work on the surface at once, so trainers can run exercises that get participants working together.

- Reach a variety of learning styles - Visual learners pick up quickly on concepts shown on interactive whiteboards and displays.

- Give trainers flexibility: trainers have the freedom to add information or follow up on new topics. If a discussion on new processes takes an unexpected turn, you can review spontaneous ideas by pulling up relevant content, whether it's a website, file or flow chart.

Training sessions supported with ICT are highly visual, hands-on experiences that engage learners and improve design decision-making. [5] Simulation is an effective teaching tool that makes complex concepts easy to grasp. This is mainly due to the active participation of the people involved in a workplace environment that simulates variability. Simulation-based learning involves the placement of a student into a realistic scenario or situation.

\section{Conclusions}

The universal training systems must provide an innovative platform for in-depth theoretical and practical education in automotive 
engineering. General requirements to learning courses are:

- Theory and practice all in one with sample solutions for students;

- PC and new media for high levels of student motivation;

- Animated theory about automotive scope for quick understanding;

- Practical competence through independent experimentation (action learning);

- Constant feedback through knowledge tests.

When teacher uses cited solutions in this article, he can offer participants a variety of methods to approach and comprehend information. Whether his group learns best by seeing, hearing or doing, he can help them understand and develop new skills.

\section{Acknowledgments}

This contribution is the result of the project implementation: "Establishing LEAN knowledge and laboratories" (acronym LEANLAB), reg. Nr. HUSK/1101/1.6.1/0161, supported by the Hungary-Slovakia Cross-border Co-operation Programme 2007-2013 funded by the European Regional Development Fund.

\section{References}

[1] KOVÁČ, M., LEŠKOVÁ, A. Inovačné centrum automobilovej výroby. Ai Magazine. 2009, Žilina - LEADERpress s.r.o., Ročník. 2, Cí́slo. 3, s. 107-109. ISSN 1337-7612

[2] KOVÁČ, M., LEŠKOVÁ, A. Aktuálne prístupy vzdelávania pre automobilovú výrobu ICAV SjF TU v Košiciach. Transfer inovácií. 2009, Košice - TU SjF, Ročník 10, Číslo 13, s. 912. ISSN 1337-7094

[3] TUKE. Faculty of Mechanical Engineering. Division of Automotive Production. (online) [cit. 2013-09-16] http://www.sjf.tuke.sk/ $\mathrm{ktam} /$ vybavenie_e.htm

[4] LUCAS-NÜLLE LEHR- UND MEßGERÄTE GMBH. Training in the Automotive Diagnostics Workshop Lab. (online) [cit. 2013-09-16] Available at: http://www.lucasnuelle.com/index.php/fuseaction/download/lrn file/automotive_engineering.pdf
[5] LUCAS-NÜLLE. Systems and trainers for vocational training and education. (online) [cit. 2013-09-18] Available at: http://www.lucasnuelle.com/301/Products/All-product-ranges.htm

[6] LUCAS-NÜLLE. Training and Further Education in Automotive Engineering. (online) [cit. 2013-09-16] Available at: http://www.technovolt.ro/cataloage/lucas\%20nue lle/AUTOMOTIVE.pdf

[7] LUCAS-NÜLLE. Automotive Technology Trainers. (online) [cit. 2013-09-16] Available at: http://www.lucas-nuelle.com/313/apg/367/

Automotive+Technology.htm

[8] LUCAS-NÜLLE. Excellence in Technology and Didactic Equipment for Education, Engineering and Vocational Education. (online) [cit. 2013-09-06] Available at: http://www.lucas-nuelle.com/271/Home.htm

[9] LUCAS-NÜLLE. Workshop. (online) [cit. 2013-09-26] Available at: http://www.lucasnuelle.com/316/apg/2722/Workshop.htm

[10] LUCAS-NÜLLE. Intelligent Lab Management for Electrical Engineering Laboratories. (online) [cit. 2013-09-22] Available at: www.lucas-nuelle.com

[11] LUCAS-NÜLLE. UniTrain-I: MobileMultimedia-Desktop Laboratory. (online) [cit. 2013-09-24] Available at: http://www.lucasnuelle.com/305/apg/1425/UniTrain-I.htm

[12] SMART TECHNOLOGIES. Manufacturing. (online) [cit. 2013-09-19] Available at: http://smarttech.com/Solutions/

Business+Solutions/Industries/Manufacturing

[13] LUCAS-NÜLLE. Training field classification. (online) [cit. 2013-09-14] Available at: http://www.lucas-nuelle.com/ 332/Training-fields.htm

Ing. Andrea Lešková, PhD.

Katedra technológií a materiálov

Strojnícka fakulta

Technická univerzita v Košiciach

Mäsiarska 74

04200 Košice, SR

Tel: +421 6023528

E-mail: andrea.leskova@tuke.sk, Www: http://www.sjf.tuke.sk/ktam/ 